Research Article

\title{
Research on Surrounding Rock Control Technology of Dongbaowei Deep Mining Roadway
}

\author{
Chengjia Wu (D), 1 Tao Qin (iD, ${ }^{2,3}$ Lei Wang $\mathbb{D}^{2},{ }^{2}$ and Zhi Liu $\mathbb{D}^{2}$ \\ ${ }^{1}$ School of Safety Engineering, Heilongjiang University of Science \& Technology, Harbin, Heilongjiang 150022, China \\ ${ }^{2}$ College of Mining Engineering of Hust, Heilongjiang University of Science and Technology, Harbin, Heilongjiang 150022, China \\ ${ }^{3}$ Heilongjiang Ground Pressure \& Gas Control in Deep Mining Key Lab, Heilongjiang University of Science \& Technology, \\ Harbin 150022, China \\ Correspondence should be addressed to Tao Qin; 19140270@qq.com
}

Received 24 November 2020; Accepted 2 January 2021; Published 19 January 2021

Academic Editor: Zhijie Wen

Copyright (c) 2021 Chengjia Wu et al. This is an open access article distributed under the Creative Commons Attribution License, which permits unrestricted use, distribution, and reproduction in any medium, provided the original work is properly cited.

\begin{abstract}
In order to explore the stability control of surrounding rock in the process of deep mining, comparative analysis of stress, deformation, and fracture characteristics of surrounding rock of deep and shallow mining roadway in dongbaotou coal mine, laboratory experiments, field measurement, numerical simulation, and field industrial experiments were adopted to put forward the control plan of the surrounding rock in deep roadway, which were verified by field industrial experiments. The results of laboratory experiments and field experiments show that the mechanical properties of deep roadway surrounding rock of Dongbaowei Coal Mine are significantly lower than those of the shadow roadway, mainly due to the development of joints and fractures of the overlying strata in the deep stope, serious impact on the disturbance of the roadway which has been made by the strong pressure of the stope, and reduced crushing strength of surrounding rock. Through comparative analysis of deep roadway support plan carried out by numerical simulation, the support scheme suitable for Dongbaowei Coal Mine is put forward, which is applied in the field. Field industrial experiments show that after the optimization of support parameters, the deformation of surrounding rock of roadway is well controlled. The displacement of surrounding rock of roadway is basically stable after $10 \sim 15$ days. The support of surrounding rock of roadway has good effect, which achieves the goal of stability control of deep roadway surrounding rock.
\end{abstract}

\section{Introduction}

With the development of coal mining technology, coal mining intensity and depth continue to increase, and shallow coal resources are depleted. Coal mine underground mining is developing at an average speed of $8.0 \sim 12.0 \mathrm{~m}$ per year, and deep coal mining in deep wells becomes the new normal of coal resource development. The complex geological conditions of deep coal resources, the increasing ground stress, the rising ground temperature, and the intensified rock mass result in a series of problems such as increased difficulty in resource exploitation, deterioration of working environment, and sharp increase in production costs, which makes safe and efficient mining in deep coal resources face challenges [1-3]. Compared with the shallow roadway, the deep well of the kilometer deep mine has high ground stress and strong mining influence, which leads to large deformation, long duration, and serious failure of the surrounding rock of the roadway $[4,5]$. Due to the strong mining behavior of the working face, the coal wall spalling, roof collapse and support failure are caused [6]. The traditional technology under shallow low stress and weak mining conditions cannot solve the problem of deep surrounding rock control [7].

The surrounding rock is a fracture driven by stress. Deep mining is in a state of high stress, so it is easier for the surrounding rock to reach the limit state, which leads to deformation and failure. In the aspect of surrounding rock control, scholars have put forward a variety of theories and technologies, from the new Austrian Tunneling Method [8-13] to the collapse arch theory [14-16]. Scholars put forward the ideas of 
surrounding rock control from the perspective of improving the bearing capacity of surrounding rock and integrating with the support. With the development of energy theory [17, 18], the interaction between surrounding rock and support is studied from the perspective of energy regulation. The former Soviet scholars [19] studied the stress state of the surrounding rock of the roadway and proposed the stress control theory. Dong et al. [20] proposed the support theory of the surrounding rock flexible range. The surrounding rock of the roadway has a certain range of loose failure under the action of stress. The main purpose of the support is to control the broken surrounding rock in the "flexible range." Zheng et al. [21-25] proposed the joint support theory according to engineering practice and believed that the surrounding rock support of roadway should adopt the principle of "flexible (support) first, rigid (support) later; yielding (support) first, compressive (support) later; moderate flexible (support) and yielding (support); stable supporting." Kang et al. [26] proposed a resin full-length prestressed anchorage combined support technology for the characteristics of low strength, loose fracture, water swelling, and easy disintegration of soft rock roadway surrounding rock mass. He et al. [27] developed a constant resistance and large deformation bolt for ordinary bolts that could not adapt to the large deformation of surrounding rock. Wang et al. [28] combined the advantages of bolts, anchor cables, and grouting, proposing the integrated support technology of bolt and grouting. Jia et al. [29] considered that high ground stress is an important factor leading to deformation of deep surrounding rock, analyzed the failure mechanism of soft rock, and proposed a support method suitable for soft rock. Liu et al. [30] analyzed the mechanical properties of columnar jointed basalt with complex stress path, which provided theoretical support for the control of surrounding rock of columnar jointed basalt.

However, most of the existing researches on surrounding rock support are directed at shallow roadways. Affected by traditional concepts, the deep roadway support has always adopted the engineering analogy method and the empirical method, which leads to the indefinite rationality of the surrounding rock control methods and technical parameters and the excessive or insufficient support strength. The disadvantage of the former is that it wastes support materials increases the cost of support, while the latter brings great hidden dangers to safe production. Based on the above, aiming at the mining characteristics of the Dongbaowei Coal Mine, the law of strata behaviors, the deformation and failure characteristics of the deep roadway, and the surrounding rock support characteristics of the roadway, this paper proposes the deep roadway surrounding rock control scheme and support parameter optimization by using laboratory experiments, field measurement, theoretical analysis, numerical simulation, and field industrial tests.

\section{Investigation and Analysis of Surrounding Rock Control in Roadway}

2.1. Mine Overview. Dongbaowei Coal Mine is located in $35 \mathrm{~km}$ east of Shuangyashan City and belongs to Shuangyashan Coalfield. The surface elevation is $+200 \mathrm{~m} \sim+260 \mathrm{~m}$, and the mining depth is $+160 \mathrm{~m} \sim-700 \mathrm{~m}$. The structure of mine area is a syncline structure with an arc distribution. The formation of north wing is gentle, with the inclination angle $10^{\circ} \sim 20^{\circ}$. The formation of south wing is steep, with the inclination angle $30^{\circ} \sim 45^{\circ}$. When the fault zone is reached, the residual tectonic stress on both sides of the fault itself superimposed with the front abutment pressure of the working face and the abutment pressure near the fault is increased to form a new high stress zone [31-37]. The No. 41 coal seam of Dongbaowei Coal Mine is affected by faults, which easily forms high stress areas and has high requirements for support. This paper takes No. 41 coal seam-350 haulage roadway in the No. 1 district of Dongbaowei Coal Mine and No. 41 coal seam-660 haulage roadway in the No. 3 district as research roadways; the difference between the buried depths of the two research roadways is $330 \mathrm{~m}$, in order to compare the effects of the surrounding rock control schemes of different buried depth entries.

2.2. Support Parameters of Roadway. The No. 41 coal seam of Dongbaowei Coal Mine has a thickness of $0.20 \sim 2.32 \mathrm{~m}$, an average thickness of $1.70 \mathrm{~m}$, and an average inclination of $30^{\circ}$. The mining depth of the No. 41 coal seam-350 m haulage roadway in the No. 1 district is $490 \mathrm{~m}$, and the buried depth of the No. 41 coal seam- 660 haulage roadway in the No. 3 district is $920 \mathrm{~m}$. The sections of the two entries and the original supporting parameters are the same. The section of the roadway is inverted trapezoid. The height of the left side is $1867 \mathrm{~mm}$, the height of the right side is $3732 \mathrm{~mm}$, and the inclination of the coal seam is $30^{\circ}$. The roadway support method is bolt and anchor cable support. The bolt support parameters are $\varphi 18 \mathrm{~mm}$ rebar anchors, and the spacing between bolts is $1200 \times 1200 \mathrm{~mm}$. Each bolt is anchored with 2 bolt-anchor agents. The length of anchor agent is $35 \mathrm{~cm}$. The anchor cable support parameters are as follows: $\varphi 17.6 \mathrm{~mm}$; length $5.3 \mathrm{~m}$. Two sets of anchor cables are installed per meter in the middle line roof of the roadway, and each anchor cable is anchored with 3 volumes of anchor agents. The supporting section parameters are shown in Figure 1.

2.3. Support Effect Analysis. The existing roadway support effect was investigated on-site, and the roadway support effect is shown in Figure 2. From the field support survey, it can be concluded that, with the same support parameters, the No. 41 coal seam-350 haulage roadway in No. 1 district has good stability and can meet the safety production needs. And, the No. 41 coal seam-660 haulage roadway roof and two sides in No. 3 district have the situation that the coal body is falling with the excavation, and the surface of the roadway is irregular and uneven partly. In the existing support, the roof anchor cable arrangement is difficult to cooperate with bolt. It is known from the existing data that the existing roadway support is combined with the empirical data of the roadways that are completed, and the engineering analogy method is used to carry out the support design of the roadway. 


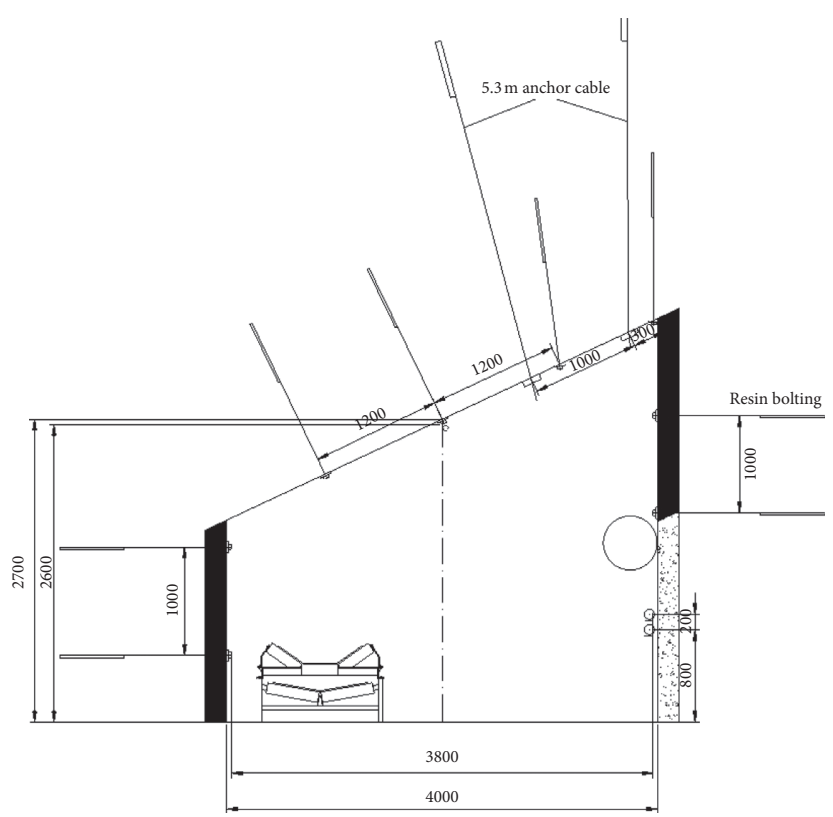

Figure 1: Support sectional.

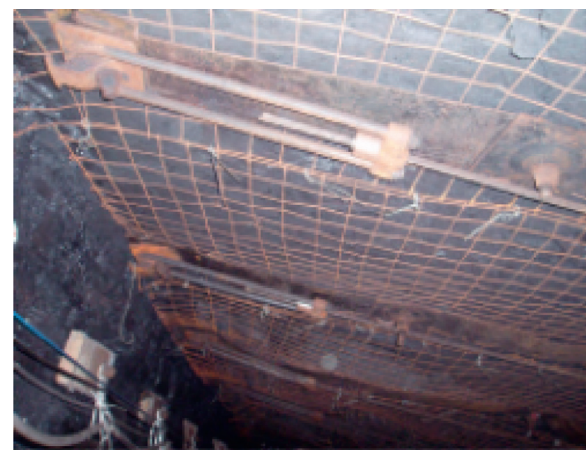

(a)

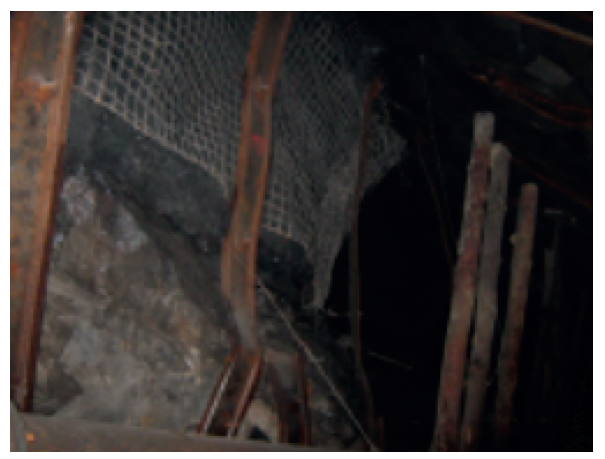

(b)

Figure 2: Roadway status. (a) No. 41 coal seam-350 haulage roadway in No. 1 district. (b) No. 41 coal seam-660 haulage roadway in No. 3 district.

The support parameters of the No. 41 coal seam-660 haulage roadway in the No. 3 district are designed by the engineering analogy method, which does not fully consider its geological conditions and mining technology factors.

The deformation and failure characteristics of the roadway of No. 41 coal seam-660 haulage roadway in the No. 3 district are analyzed as follows:

(1) The mining depth increases the failure of the surrounding rock of the two sides and the roof: the root cause of deformation and failure of surrounding rock is stress. The deeper the mining depth is, the greater the stress of surrounding rock is, which leads to the failure of surrounding rock when it reaches the limit stress condition. Under the action of tangential stress, the surrounding rock at the top and two sides of the roadway is in a post peak state, which leads to the fragmentation of surrounding rock on the roadway surface. The No.
41 coal seam-660 haulage roadway in No. 3 district is difficult to support, because of the high support cost and the low efficiency. The roadway has obvious convergence and the deformation of the surrounding rock is large.

(2) : Distribution and mechanical properties of surrounding rock of roadwaythe structural planes such as joints and fissures in the surrounding rock of No. 41 coal seam-660 haulage roadway in No. 3 district are affected by geological structures such as faults and folds. When the surrounding rock is subjected to the dynamic pressure of working face, severe discontinuous deformations and failures occur. The roof and the two sides are soft and broken coal bodies, and the convergence is severe. The bolts and anchor cables in the existing support of the roadway are broken, and some bolts, anchor rods, and trays are detached and leaked from mesh. 
(3) The working face support pressure peak is high and its influence range is large: the distribution and properties of the roof strata directly affect the first weighting of the working face, the periodic weighting interval, the compressive strength of the weighting, and the collapse state of the strata in the goaf, which in turn affects the influence range and dimension of mining impact on the mining face. The caving height of the overburden strata and the height of the fissure zone on the working face of the No. 41 coal seam-660 haulage roadway in No. 3 district are large. The peak of front abutment pressure of the working face and the peak of side abutment pressure of the working face are high, and the weighting of working face is fierce. The periodic weighting interval is about $15-19 \mathrm{~m}$, which has serious disturbance effect on the stability of the roadway ahead. With the mining of the working face, the structural state and stress state of the roadway are constantly changing, which further aggravates the difficulty of support.

\section{Test and Analysis of Physical and Mechanical Properties of Coal and Rock}

3.1. Test Piece Processing and Test Methods. Considering the surrounding rock occurrence conditions of the roadway, the coal seam and the roof of the No. 41 coal seam-350 m elevation and $-660 \mathrm{~m}$ elevation were sampled, respectively, and the mechanical parameters were tested and analyzed. According to the requirements of international rock mechanics test, 80 cylindrical coal and rock sample specimens with a diameter of $50 \mathrm{~mm}$ and a height of $100 \mathrm{~mm}$ were processed in the laboratory. The coal and rock samples are shown in Figure 3.

The Sonic Viewer-SX ultrasonic speed test system was used to test and screen the acoustic wave of the test piece, and the test piece with a wave speed of about $2000 \mathrm{~m} / \mathrm{s}$ was selected for testing to reduce the discreteness of the test piece. The mechanical parameters such as uniaxial compressive strength of coal rock samples were tested by TAW2000 electrohydraulic servo test machine. The experimental devices are shown in Figure 4.

3.2. Experimental Results. The test results of the mechanical parameters of the coal seams and floors of different depths of No. 41 coal seams in Dongbaowei Coal Mine are shown in Table 1 .

The average uniaxial compressive strengths of coal seam and roof rock in No. 41 coal seam -350 haulage roadway of No. 1 district are $12.60 \mathrm{MPa}$ and $82.3 \mathrm{MPa}$, respectively. The average uniaxial compressive strengths of coal seam and roof rock in No. 41 coal seam -660 haulage roadway of No. 3 district are 9.66 $\mathrm{MPa}$ and $63.55 \mathrm{MPa}$, respectively. It can be seen from the test results of the surrounding rock mechanical parameters of the roadway that the mechanical properties of the surrounding rock of the No. 41 coal seam$660 \mathrm{~m}$ elevation coal seam and the roof and floor of the No. 3 district are significantly lower than those of the $-350 \mathrm{~m}$ elevation, because the overburden structural planes such as joints and fissures on the working face of the -660 haulage roadway are developed. The strong weighting from the working face has a serious impact on the disturbance of the mining roadway, and the crushing strength of surrounding rock is reduced.

\section{Optimization Study on Surrounding Rock Control Parameters of Roadway}

In order to analyze the support parameters and the stability control of surrounding rock of No. 41 coal seam-660 haulage roadway in No. 3 district of Dongbaowei Coal Mine, different surrounding rock control support schemes and supporting parameters were proposed, and FLAC ${ }^{3 \mathrm{D}} \mathrm{nu}-$ merical simulation software was used to analyze the supporting effect.

4.1. Numerical Simulation Analysis of Supporting Scheme. From the perspective of analyzing and comparing the influence of support and mining on the stability of roadway surrounding rock, the unsupported, bolt support and boltanchor cable support model were established, as shown in Figure 5. According to the above model, the stress distribution and the displacement distribution of the surrounding rock under unsupported conditions, bolt support conditions, and bolt-anchor cable support conditions are obtained, as shown in Figures 6 and 7.

It can be seen from the simulation results that, in the unsupported state, the stress concentration of the surrounding rock of the roadway is obvious, and the displacement of the roof of the roadway is large. The stress concentration of the surrounding rock of the bolt support roadway is weakened and the displacement is reduced. The bolt support has a good control effect on the surrounding rock deformation of the roadway. After the bolt and anchor cable combined support, the stress distribution of the roadway has obvious changes and the stress distribution of the roadway side is evenly distributed. The displacement of the bolt and anchor cable support roadway is obviously reduced, and the displacement is mainly concentrated in the roof of the roadway, which should be more careful when supporting. It can be seen from the numerical simulation that stress distribution of the bolt-anchor cable support is more uniform and the displacement is smaller.

4.2. Numerical Simulation Analysis of Support Parameters. According to the field measurement, the maximum roof loosening range of the No. 41 coal seam-660 haulage roadway in No. 3 District of Dongbaowei $3 \mathrm{~m}$ (the loose range of the top) and $2 \mathrm{~m}$ (the loose range of the two sides). Considering the broken roof of the roadway and the relatively large displacement, the roof bolt support is strengthened. The roof bolt with $\varphi 18 \mathrm{~mm}$ and length $2.9 \mathrm{~m}$ was selected. The roof anchor cable with $\varphi 17.6 \mathrm{~mm}$ and length $9.6 \mathrm{~m}$ was selected. The three-row spacing parameters between bolts were designed for comparative analysis. The 


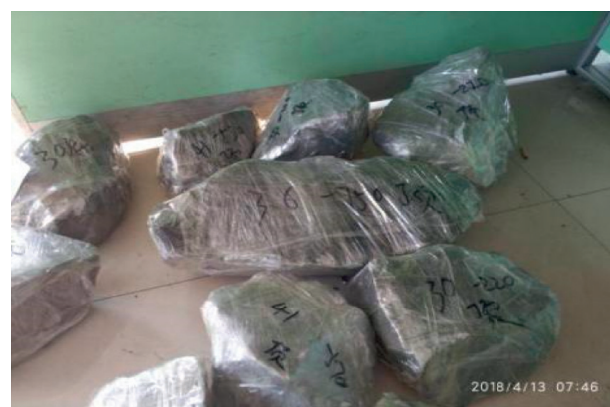

(a)

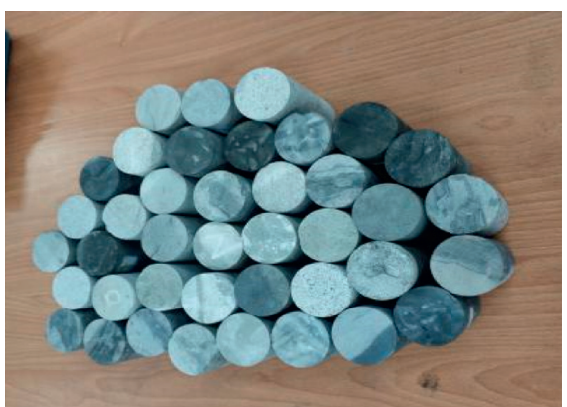

(b)

Figure 3: Sample of coal and rock. (a) On-site sampled rock mass. (b) Processed standard sample.

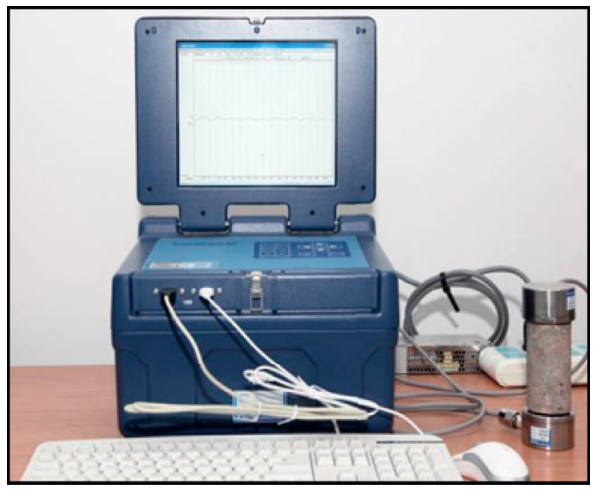

(a)

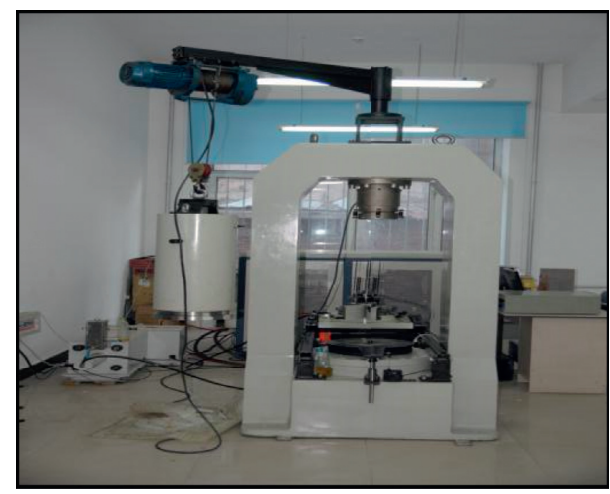

(b)

FIgURE 4: Experimental facility. (a) Rock sample ultrasonic testing system. (b) TAW-2000 electrohydraulic servo testing machine.

TABLE 1: Test results of mechanical parameters.

\begin{tabular}{|c|c|c|c|c|c|c|c|}
\hline Roadway strata & $\begin{array}{l}\text { Test piece } \\
\text { number }\end{array}$ & $\begin{array}{l}\text { Density } \\
\left(\mathrm{kg} \cdot \mathrm{m}^{-3}\right)\end{array}$ & $\begin{array}{c}\text { Elastic } \\
\text { modulus } \\
(\mathrm{GPa})\end{array}$ & $\begin{array}{l}\text { Poisson } \\
\text { ratio }\end{array}$ & $\begin{array}{c}\text { Uniaxial compressive } \\
\text { strength } \\
(\mathrm{MPa})\end{array}$ & $\begin{array}{l}\text { Uniaxial tensile } \\
\text { strength } \\
(\mathrm{MPa})\end{array}$ & $\begin{array}{l}\text { Shear strength } \\
(\mathrm{MPa})\end{array}$ \\
\hline \multirow{3}{*}{$\begin{array}{l}\text { No. } 41 \text { coal seam of } \\
350 \mathrm{~m} \text { elevation }\end{array}$} & QM1 & 1343.52 & 2.23 & 0.36 & 11.71 & 1.68 & 6.85 \\
\hline & QM2 & 1347.85 & 2.35 & 0.35 & 13.57 & 1.85 & 7.45 \\
\hline & QM3 & 1335.54 & 2.16 & 0.37 & 12.51 & 1.74 & 7.25 \\
\hline \multirow{3}{*}{$\begin{array}{l}\text { No.41 coal seam of } \\
660 \mathrm{~m} \text { elevation }\end{array}$} & SM1 & 1365.21 & 2.56 & 0.37 & 10.21 & 1.56 & 6.51 \\
\hline & SM2 & 1368.20 & 2.98 & 0.39 & 9.54 & 1.34 & 6.86 \\
\hline & SM3 & 1335.42 & 2.78 & 0.34 & 9.24 & 1.38 & 6.41 \\
\hline \multirow{3}{*}{$\begin{array}{l}\text { Roadway roof of } 350 \mathrm{~m} \\
\text { elevation }\end{array}$} & SY1 & 2784.21 & 19.65 & 0.18 & 72.65 & 10.02 & 54.39 \\
\hline & SY2 & 2618.07 & 16.9 & 0.15 & 77.13 & 11.25 & 53.295 \\
\hline & SY3 & 2616.36 & 18.88 & 0.16 & 97.12 & 13.11 & 39.66 \\
\hline \multirow{3}{*}{$\begin{array}{l}\text { Roadway roof of } 660 \mathrm{~m} \\
\text { elevation }\end{array}$} & QY1 & 2596.33 & 21.34 & 0.17 & 52.91 & 10.06 & 32.805 \\
\hline & QY2 & 2765.06 & 22.55 & 0.15 & 71.37 & 13.85 & 50.52 \\
\hline & QY3 & 2675.24 & 20.54 & 0.16 & 66.38 & 13.21 & 38.88 \\
\hline
\end{tabular}

row spacing parameters were as follows: scheme 1 $1.0 \mathrm{~m} \times 0.8 \mathrm{~m}$, scheme $21.0 \mathrm{~m} \times 1.0 \mathrm{~m}$, and scheme 3 $1.0 \mathrm{~m} \times 1.2 \mathrm{~m}$. Numerical simulation analysis of the three schemes is shown in Figures 8 and 9.

It can be seen from the numerical simulation results that the stress concentration of the surrounding rock of the roadway and the deformation of the surrounding rock were controlled by strengthening the roof bolt and anchor cable support. Compared with different row spacing of bolts, the stress distribution in the $z$ direction of the roadway is more uniform when the spacing is $1.0 \mathrm{~m} \times 0.8 \mathrm{~m}$. When the spacing is $1.0 \mathrm{~m} \times 1.0 \mathrm{~m}$, the stress concentration appears in the roof of the roadway. When the spacing is $1.0 \mathrm{~m} \times 1.2 \mathrm{~m}$, the stress concentration appears in the floor of the roadway. When the bolt spacing increases, the stress concentration range increases and the stress concentration degree also 


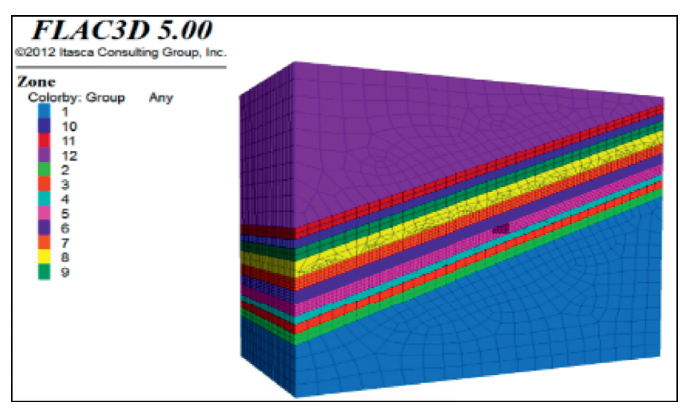

(a)

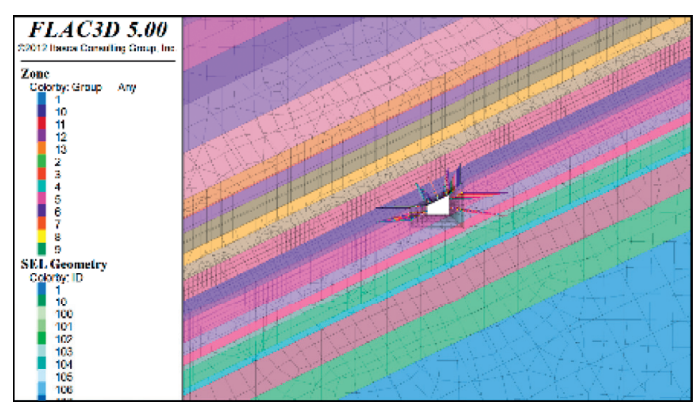

(b)

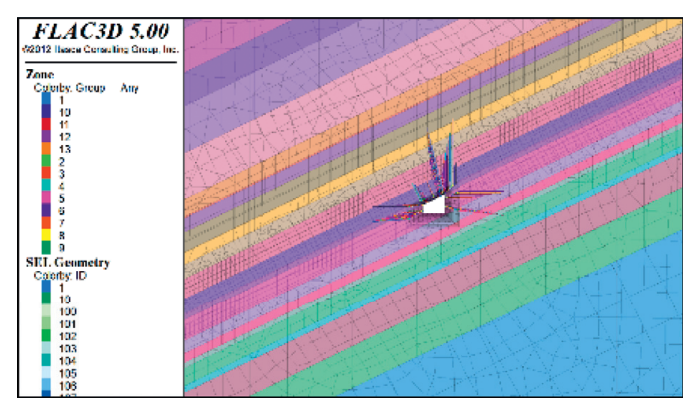

(c)

FiguRE 5: Support model. (a) Unsupported. (b) Bolt support. (c) Bolt-anchor cable support.

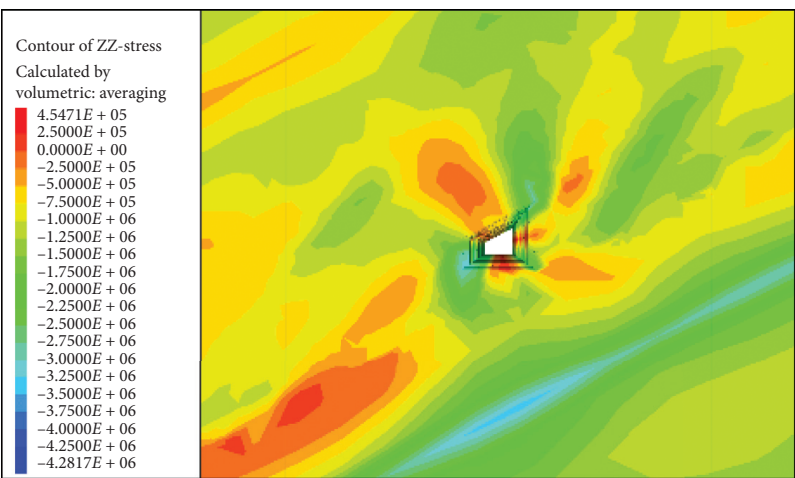

(a)

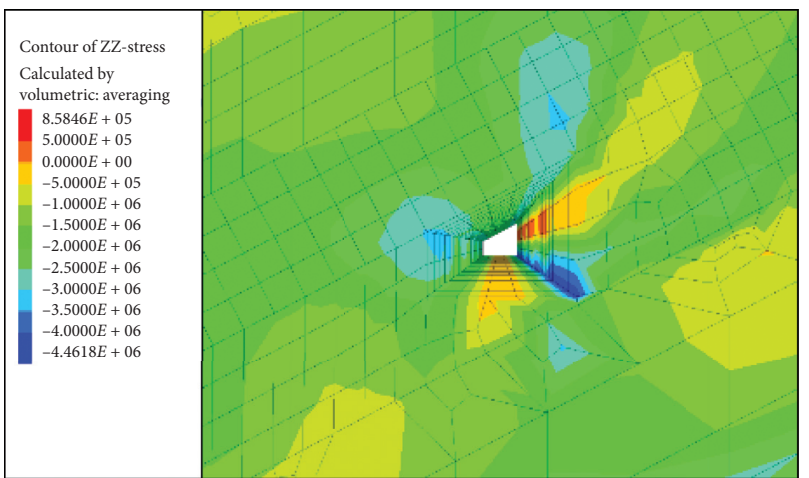

(b)

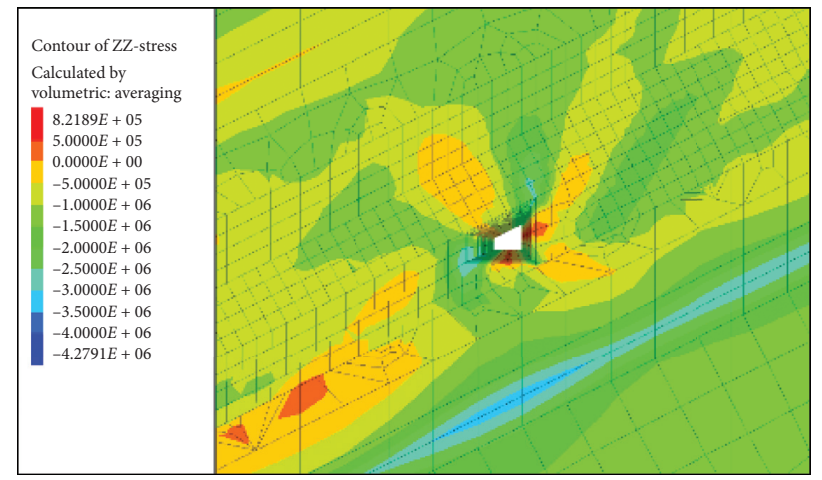

(c)

Figure 6: Stress distribution. (a) Unsupported. (b) Bolt support. (c) Bolt-anchor cable support. 


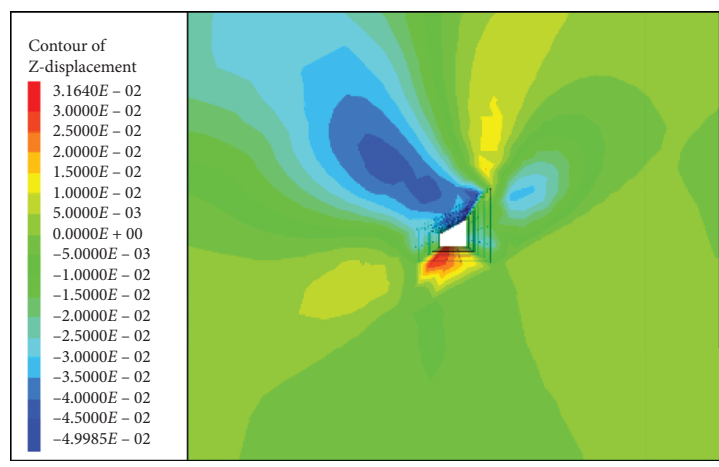

(a)

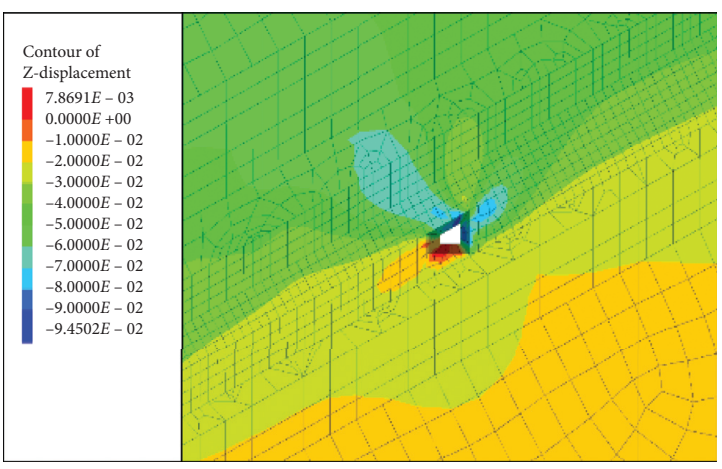

(b)

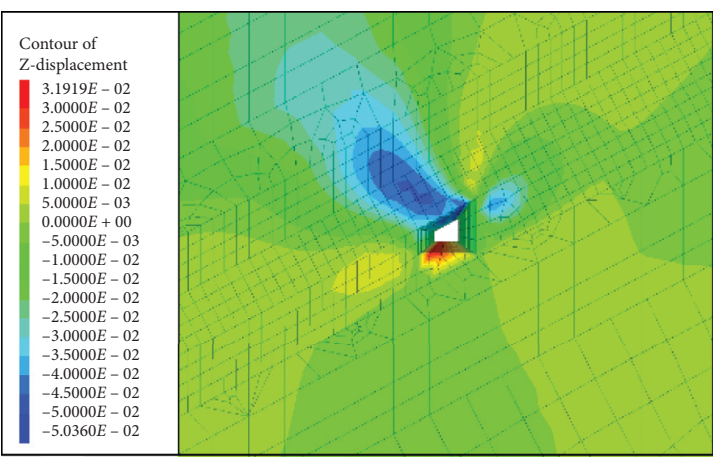

(c)

Figure 7: Displacement distribution. (a) Unsupported. (b) Bolt support. (c) Bolt-anchor cable support.

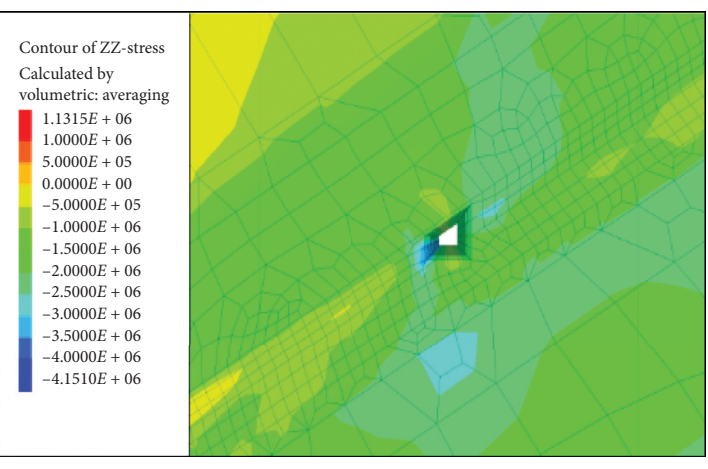

(a)

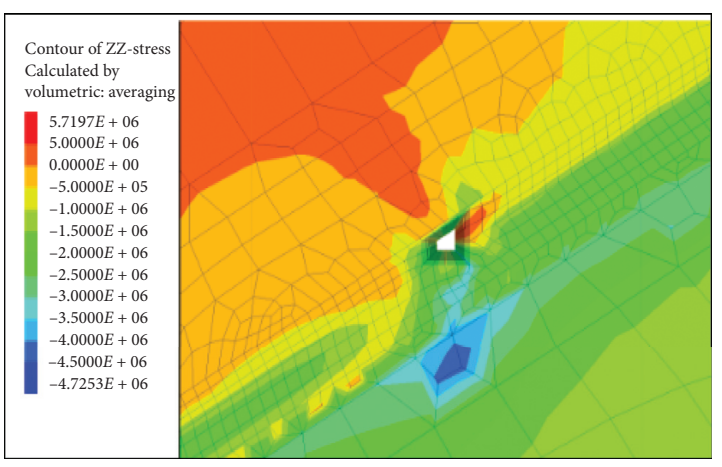

(b)

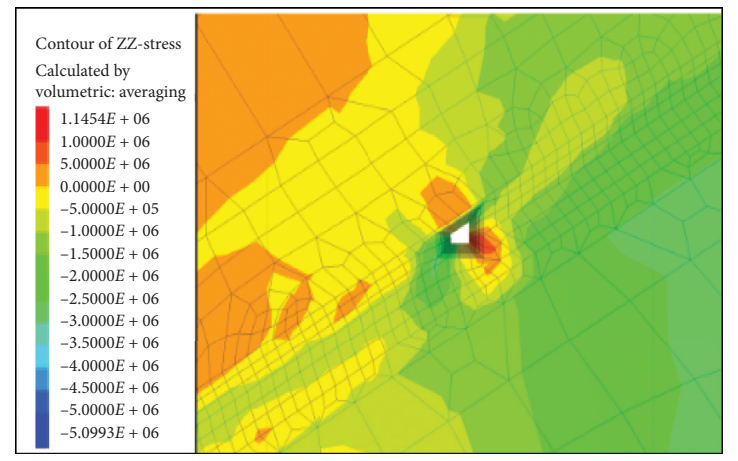

(c)

Figure 8: Stress distribution. (a) Scheme 1: interval $1.0 \mathrm{~m} \times 0.8 \mathrm{~m}$. (b) Scheme 2: interval $1.0 \mathrm{~m} \times 1.0 \mathrm{~m}$. (c) Scheme 3: interval $1.0 \mathrm{~m} \times 1.2 \mathrm{~m}$. 


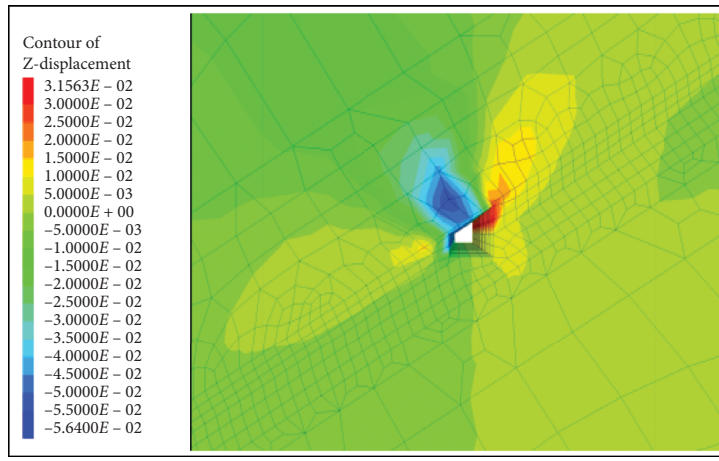

(a)

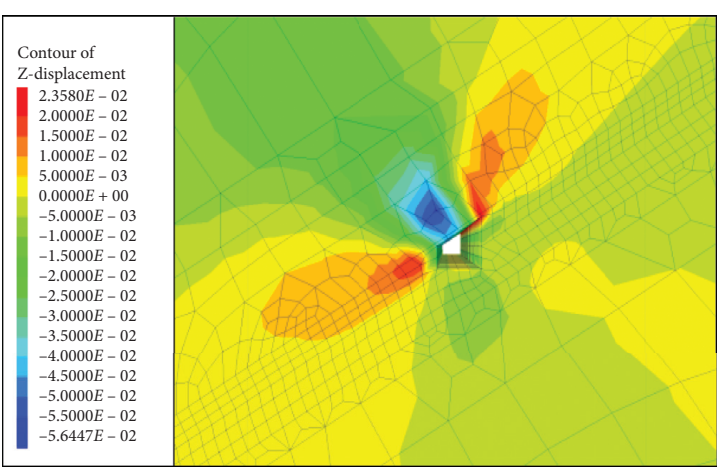

(b)

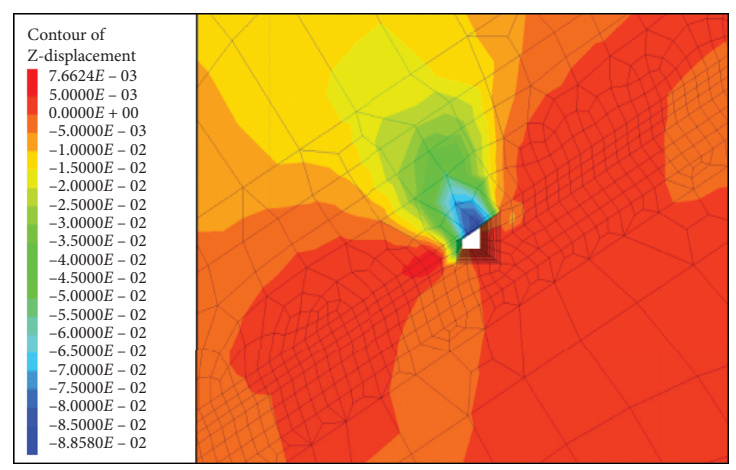

(c)

Figure 9: Displacement distribution. (a) Scheme 1: interval $1.0 \mathrm{~m} \times 0.8 \mathrm{~m}$. (b) Scheme 2: interval $1.0 \mathrm{~m} \times 1.0 \mathrm{~m}$. (c) Scheme 3: interval $1.0 \mathrm{~m} \times 1.2 \mathrm{~m}$.

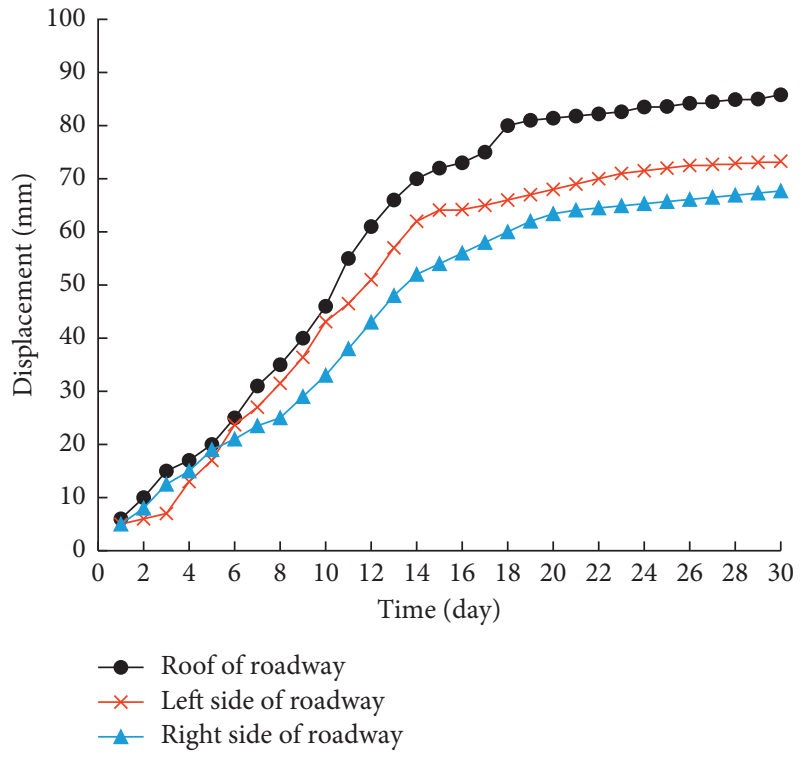

(a)

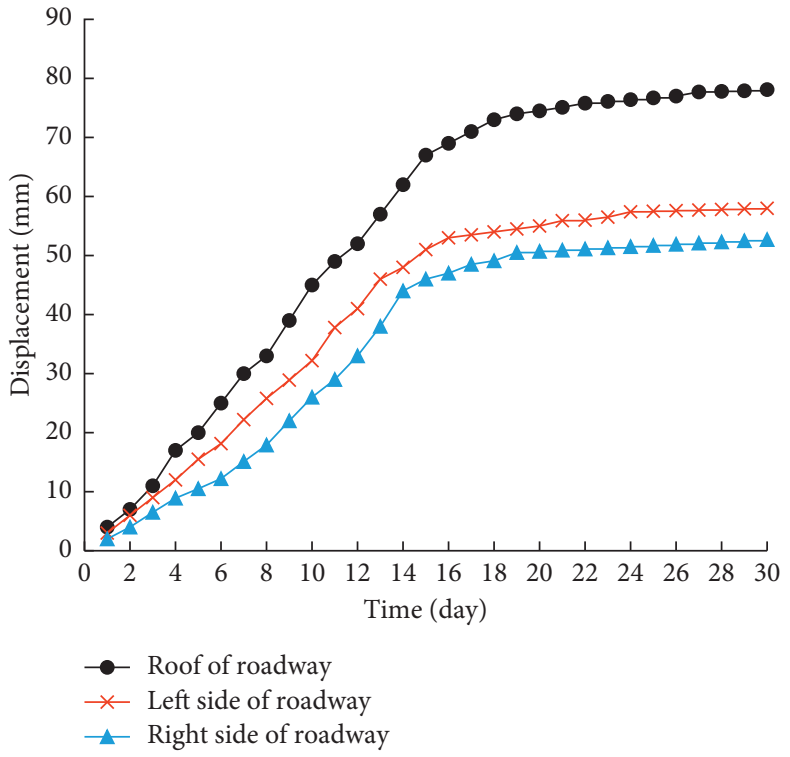

(b)

Figure 10: Observation results of roadway Surface displacement. (a) The first measuring point. (b) The second measuring point.

increases. Compared with scheme 2 and scheme 3 , the deformation of the surrounding rock of scheme 1 is obviously reduced. The roof of scheme 3 has obvious subsidence, and the maximum subsidence is $0.09 \mathrm{~m}$. From the simulation results, both scheme 1 and scheme 2 can meet the requirements of safe production. Comprehensively 
considering the engineering quality and geological conditions during roadway construction and leaving a certain surplus support space, scheme 1 is more suitable.

Through the above numerical simulation analysis, it can be seen that the supporting parameters of the No. 41 coal seam-660 m deep roadway in the original No. 3 dirstrict of Dongbaowei Coal Mine need to be further strengthened. It is suggested that the row spacing between the bolts in the deep mining roadway of No. 41 coal seam in the No. 3 district should be adjusted from $1.2 \mathrm{~m} \times 1.2 \mathrm{~m}$ to $1.0 \mathrm{~m} \times 0.8 \mathrm{~m}$. The length of the roof anchor cable is adjusted from $5.3 \mathrm{~m}$ to $9.6 \mathrm{~m}$.

\section{Field Industrial Experiment}

In order to test the rationality of the optimized support parameters, a $50 \mathrm{~m}$ roadway was selected in the No. 41 coal seam deep roadway for the industrial test. The test roadway is No. 41 coal seam-640 right haulage roadway, with a trapezoidal roadway section, the left side height is $2144 \mathrm{~mm}$, and the right side height is $3473 \mathrm{~mm}$. The support scheme is as follows.

The roof support was made of $2.9 \mathrm{~m}$ long and $\varphi 18 \mathrm{~mm}$ rebar anchors. The two sides were supported by $\varphi 16 \mathrm{~mm}$ and $2.9 \mathrm{~m}$ long bolts. The spacing between bolts is $0.8 \mathrm{~m} \times 1.0 \mathrm{~m}$. $\varphi 17.6 \mathrm{~mm}$ and $9.6 \mathrm{~m}$ long anchor cable was selected to support, and the spacing between the cables is $1.0 \mathrm{~m} \times 1.0 \mathrm{~m}$.

Two measuring points were arranged, the measuring point spacing is $20 \mathrm{~m}$, and the cross-track method was used to monitor the displacement of the roadway every two days. According to the actual width of the roadway, the steel tape, the tape measure, the bolt, and the engineering line with the length of $5 \mathrm{~m}$ were selected to monitor the displacement of roadway surface. The results of the field observation are shown in Figure 10.

Through field industrial test and observation, it can be concluded that the deformation of the surrounding rock of the roadway is well controlled by the optimization of support parameters. The displacement of the surrounding rock of the roadway is basically stable after $10 \sim 15$ days, and the surrounding rock support effect of the roadway is better. It improves the safety of roadways and provides safety for subsequent mining.

\section{Conclusion}

In this paper, aiming at the stability problem of deep roadway support in Dongbao coal mine, based on the field investigation, the existing problems of deep mining roadway support in Dongbao coal mine were analyzed. Through laboratory experiments and numerical simulation analysis, the support scheme and parameters of deep roadway in Dongbao coal mine were optimized and verified by field industrial tests. The main conclusions are as follows:

(1) The mechanical properties of the surrounding rock of No. 41 coal seam- $660 \mathrm{~m}$ elevation are significantly lower than those of the $350 \mathrm{~m}$ elevation, which is mainly due to the development of structural planes such as overlying joints and fissures in the working face. The disturbance of the mining roadway is affected by the strong weighting of the working face, and the crushing strength of the surrounding rock is reduced.

(2) Through numerical simulation, the optimal supporting scheme of No. 41 coal seam deep mining roadway was determined as follows: bolt parameters: $\varphi 18 \mathrm{~mm}$, length $2.9 \mathrm{~m}$, and row spacing between bolts $0.8 \mathrm{~m} \times 1.0 \mathrm{~m}$; anchor cable parameters $\varphi 17.6 \mathrm{~mm}$, length $9.6 \mathrm{~m}$, and distance between anchor cables $1.0 \mathrm{~m} \times 1.0 \mathrm{~m}$.

(3) Through the field industrial experiment, after the optimization of support parameters, the deformation of the surrounding rock of the roadway is well controlled. The displacement of the surrounding rock of the roadway is basically stable after $10 \sim 15$ days, and the surrounding rock support effect of the roadway is better. It improves the safety of roadways and provides safety for subsequent mining.

\section{Data Availability}

The data used to support the findings of this study are available from the corresponding author upon request (e-mail: 19140270@qq.com).

\section{Conflicts of Interest}

The authors declare no conflicts of interest.

\section{Acknowledgments}

The research presented in this paper has been supported jointly by the National Natural Science Foundation (NNSF) of China (Grant no. 51674107), the National Key Research and Development Program (Grant no. 2016YFC0600901), and Joint Guidance Project of Natural Science Foundation of Heilongjiang Province (LH2019E087).

\section{References}

[1] H. Xie, "Research review of the state key research development program of China: deep rock mechanics and mining theory," Journal of China Coal Society, vol. 44, no. 5, pp. 1283-1305, 2019.

[2] H. Xie, "Research framework and anticipated results of deep rock mechanics and mining theory," Advanced Engineering Sciences, vol. 49, no. 2, pp. 1-16, 2017.

[3] H. Xie, Z. Zhang, F. Gao et al., "Stress-fracture-seepage field behavior of coal under different mining lay-outs," Journal of China Coal Society, vol. 41, no. 10, pp. 2405-2417, 2016.

[4] H. Xie, F. Gao, and J. U. Yang, "Research and development of rock mechanics in deep ground engineering," China Journal of Rock Mechanics and Engineering, vol. 34, no. 11, pp. 2161-2177, 2015.

[5] H. Kang, J. Wang, and J. Lin, "High pretensioned stress and intensive bolting system and its application in deep roadways," Journal of China Coal Society, vol. 32, no. 12, pp. 1233-1238, 2007. 
[6] G. Sun, S. Zhu, F. Jiang et al., "Safe mining technology at strong dynamic pressure area in deep extra-thick coal seam," Journal of China Coal Society, vol. 40, no. S1, pp. 12-18, 2015.

[7] H. Kang, G. Wang, P. Jiang et al., "Conception for strata control and intelligent mining technology in deep coal mines with depth more than 1000 m," Journal of China Coal Society, vol. 43, no. 7, pp. 1789-1800, 2018.

[8] N. R. Barton and E. Grimstad, "Rock mass conditions dictate choice between NMT and NATM," Tunnels and Tunnelling, vol. 26, no. 10, pp. 39-42, 1994.

[9] L. V. Rabcewicz, "The new Austrian tunnelling method," Water Power, vol. 17, no. 1, pp. 511-515, 1964.

[10] I. W. Farmer, "Stress distribution along a resin grouted rock anchor," International Journal of Rock Mechanics and Mining Sciences \& Geomechanics Abstracts, vol. 12, no. 12, pp. 347351, 1975.

[11] E. T. Brown, "Putting the NATM into perspective," Tunnels and Tunneling, vol. 13, no. 10, 1990.

[12] L. V. Rabcewicz, "The new Austrian tunneling method," Water Power, vol. 17, no. 4, pp. 19-24, 1965.

[13] L. V. Rabcewicz, "Stability of tunnels under rock load," Water Power, vol. 21, no. 7, pp. 225-273, 1969.

[14] M. Cai, M. He, and D. Liu, Rock Mechanics and Engineering, Science Press, Beijing, China, 2002.

[15] E. Hoek, C. Carranza-Torres, and B. Corkum, "Hoek-Brown failure criterion-2002 edition," in Proceedings of the NARMSTAC 2002, Mining Innovation an Technology, pp. 267-273, University of Toronto, Toronto, Canada, January 2002.

[16] E. Hoek, Practical Rock Engineering, Evert Hoek Consulting Engineer Inc., North Vancouver, Canada, 2006.

[17] M. Gao, N. Zhang, L. Dou et al., "Study of roadway support parameters subjected to rock burst based on energy balance theory," Journal of China University of Mining \& Technology, vol. 36, no. 4, pp. 426-430, 2007.

[18] Z. Zhao, B.-T. Tang, and X.-Y. Ruan, "Energy based 3D mapping algorithm to solve initial solution for inverse analysis in sheet metal forming," Journal of Plasticity Engineering, vol. 3, no. 14, pp. 45-48, 2007.

[19] G. Hui and J. Song, "Combined supporting technology with pressure releasing and yielding in road-way under combined roof with high stress," Journal of Xi'an University of Science and Technology, vol. 30, no. 4, pp. 412-415, 2010.

[20] F. Dong, H. Song, Z. Guo et al., "Roadway support theory based on broken rock zone," Journal of China Coal Society, vol. 19, no. 1, pp. 21-32, 1994.

[21] O. Aydan, "The stabilization of rock engineering structure by bolts,” A. A. Balkema, Rotterdam, Netherlands, 1989.

[22] Y. Zheng, The Theoretical Basis of Elastic-Plastic Viscosity in Rock Mechanics, Coal Industry Press, Beijing, China, 1988.

[23] P. Williams, "The development of rock bolting in UK coal mining," Mining Engineer, vol. 153, pp. 307-312, 1994.

[24] O. Aydan, The Stabilization of Rock Engineering Structure by Bolts, A. A. Balkema, Rotterdam, Netherlands, 1989.

[25] S. Yazici and P. K. Kaiser, "Bond strength of grouted cable bo1ts," International Journal of Rock Mechanics and Mining Science \& Geomechanics Abstracts, vol. 3, 1992.

[26] H. Kang, J. Wang, and J. Lin, "Case study of rock bolting in coal mine roadways," Chinese Journal of Rock Mechanics and Engineering, vol. 29, no. 4, pp. 649-664, 2010.

[27] M. He and H. Yuan, Theory and Practice of Bolt Support in Coal Mine of China, Science Press, Beijing, China, 2004.

[28] L. Wang, Y. Lu, Y. Huang et al., "Study on deep-shallow coupled full-section bolting and grouting support in deep soft rock roadway," Journal of China University of Mining and Technology, vol. 45, no. 1, pp. 11-18, 2016.

[29] H. Jia and H. Wang, "Principle and application of the double cacheable and gradually deformable supporting shells for soft rock tunneling," Rock and Soil Mechanics, vol. 36, no. 4, pp. 1119-1126, 2015.

[30] L. Gang, F.-K. Xiao, Q.-L. Cheng, and Q. Tao, "Experimental study on acoustic emission characteristics of dry and saturated basalt columnar joints under uniaxial compression and tensile damage," Shock and Vibration, vol. 2019, Article ID 4971695, 12 pages, 2013.

[31] J. Wang, Z. Wang, H. Ding, B. Guo, and X. Gu, "Research and application of composite support technology based on concrete filled steel tubular scaffold of fault fracture zone roadway," Tunnel Construction, vol. 38, no. 2, pp. 277-286, 2018.

[32] Z. Wang, J. Yang, and H. Meng, "Mechanism and controlling technology of rib spalling in mining face with large cutting height passing through fault," Journal of China Coal Society, vol. 40, no. 1, pp. 42-49, 2015.

[33] X. Lai, J. Zheng, J. Chen et al., "Comprehensive identification of rock-coal mass internal critical destabilization in fault influenced broken zone," Journal of China Coal Society, vol. 40, no. S1, pp. 1-5, 2015.

[34] W. Song, M. Shi, C. Zhao et al., "Study on fracture zone of cross fault group in large section rectangular roadway undermining conditions," Coal Science and Technology, vol. 46 , no. 10 , pp. $117-124,2018$.

[35] Ö Aydan, T. Akagi, and T. Kawamoto, "The squeezing potential of rocks around tunnels; theory and prediction; theory and prediction," Rock Mechanics and Rock Engineering, vol. 26, no. 2, pp. 137-163, 1993.

[36] G. Anagnostou, "A model for swelling rock in tunnelling," Rock Mechanics and Rock Engineering, vol. 26, no. 4, pp. 307-331, 1993.

[37] X. Mao, X. Miao, and M. Qian, "Study on broken laws of key strata in mining overlying strata," Journal of China University of Mining and Technology, vol. 27, no. 1, pp. 39-42, 1998. 